\title{
Reflections on the media coverage of the Anglican Church management conflict in Zimbabwe.
}

\author{
Dr Edmore Dube and Innocent Fungai Chiyadzwa \\ Great Zimbabwe University
}

\begin{abstract}
This paper explored the different views and dimensions that emerged during the conflict for leadership in the Anglican Church in Zimbabwe between the year 2000 and 2013. It is not disputed that the media act as a watchdog of the society, but in the Anglican conflict it is a mystery as to whose dog the media was as evidenced by a close analysis of the comments they wrote. While it is evident and undoubtedly clear that the religious conflicts for leadership dates back to the biblical days, it is still worthwhile to expound on whether the old motivations for leadership are the same as those obtaining in the Anglican conflict. An analysis is thus essential so as to draw parallels between the ancient church leadership squabbles and the contemporary Anglican crisis. Relying mainly on newspaper documentary evidence, this paper explored the media's neutrality and role in the Anglican management conflict. The results showed that the media are active agenda setters who frame issues in a certain manner while ignoring or censoring other dimensions. From the perspectives of the public it was noted that the congregation got aligned to different media organizations, which shared their views in the unfolding disagreements. The old theories of succession and the spirit of schism slid back into place in a very glaring way; with power, priestly preeminence and prophetic authority taking the centre stage in the conflict in an interesting way.

Key words: Anglican Management Conflict, Agenda Setting Theory, Factionalism, Prophetic Authority, Church of the Province of Central Africa (CPCA), Church of the Province of Zimbabwe (CPZ).
\end{abstract}

\section{Introduction}

The Anglican conflict emanated from the year 2000 when Reverend Tim Neil largely tipped to lend the post of Archbishop of Harare lost the election to Nolbert Kunonga. Prior to the election Neil had become a strong critic of President Robert Mugabe who had embarked on the Fast Track Land Reform Programme. Neil used an array of strategies to launch a strong anti-Mugabe crusade within the church and in collaboration with civic society courted the ire of the Robert Mugabe led Zimbabwe African National Union Patriotic Front (ZANU PF) government. Seeking to eliminate opposition politics from the pulpit Anglicans preferred Kunonga to Neil. Contrary to the expectations, Kunonga overleapt and declared his unwavering support for ZANU PF and its policies on land and homosexuality. The media reacted to the resultant protracted battle to oust Kunonga through news articles, opinion pieces and feedback letters, prompting this paper to critic the role played by the print media through its agenda setting strategies.

This study is confined to public and private newspaper stables that run daily newspapers. Public newspapers have the state as the majority shareholder and are controlled directly through state appointed boards. The private press is owned by consortiums of business people who are independent of the state. The public media is run by The Zimbabwe Newspaper Group, popularly known as Zimpapers, which runs The Herald and The Sunday Mail among others. In the private media there are two newspaper stables that run daily newspapers namely The Associated Newspaper Group (ANZ) and Alpha Media Holdings (AMH). ANZ run The Daily News and The Daily News on Sunday. AMH owns and runs Newsday and two weeklies The Independent and The Standard.

\section{Hypothesis}

In a polarized society like Zimbabwe where the media is visibly divided, the different factions may have found solace in the divided media whose idolizing readers must have been puffed up to go their parallel ways, leaving the observer stranded in the middle of the park wondering which feuding side harbored the truth.

\section{Justification}

Any knock on the society's well-being is an irresistible bait for any serious scholar to take remedial action through the power of the pen. The turmoil that the CPCA went through was of a sufficient magnitude to warrant exploration in context. Reading one section of the media (private or public) oblivious of the other one tended to be sucked into the particular faction whose agenda was being propagated by the section and tempted into wondering why the other faction was being so insane to go contrary to the truth. But on being aware of the 
other side one was left more puzzled as to which media section was being fair to the protagonists. Objectivity and fairness as the marks of any scholarly work has caused this inquiry to take off with the view of finding out what the real facts were and how they were variously disseminated in the sections of the media. As turmoil in the sanctuary of God has been experienced as early as the biblical times, the researchers found it fair to discuss the Anglican feud within the biblical and historical contexts before examining what role the media played in fanning it.

\section{The theory of succession and the spirit of schism}

\section{- (i) The Biblical Succession}

The story of King David sets the whole agenda in motion (Anderson, 1990, p.229). King David appointed Zadok, a man of questionable priestly background to the position of a rival chief priest. The position was traditionally enjoyed by the Levites to whom Abiathar the legitimate chief priest belonged. What ensued was a nasty factional alignment pitting 'prophet' Nathan, priest Zadok and Beniah the deputy army commander mother supporting the unorthodox accession of Solomon to power, against the faction led by Abiathar the legitimate chief priest, Gad the prophet and Joab the army commander supporting the traditional bid of the eldest son Adonijah (I Kings 1\&2). The illegitimate faction triumphed resulting in either expulsion or decapitation of the members of the legitimate Abiathar faction. This poisoned chalice emboldened Ahijah the prophet of Shiloh to accelerate the schismatic nature of the Davidic Empire through the anointment of Jeroboam the secessionist (I Kings 11). Jeroboam seceded from the united Israel with ten of the richest tribes leaving Rehoboam, Solomon's son with two.

The current paper wishes to discern the nature and causes of the factional alignments within the Anglican Communion of Central Africa. The biblical scenario above has 'political power,' 'priestly intercessory preeminence' and 'prophetic authority' as contested, and the key carriers of factionalism. The alliance amongst the three offices tends to open up the avenues to resources and self- actualization. Does the question of legitimate self-actualization arising from this contest have any implications in the Anglican saga?

\section{(ii) The Prophetic Theory}

A prophet is someone who stands in the council of God (Ewbank, 1994, p.31). A prophet is called by God for a specific mission (Anderson, 1975, p.252). Moses was called to liberate the slaves suffering at the hands of the Egyptians in Egypt, while Amos was called to correct the merciless exploitation of the poor by the corrupt Israelite regime in Samaria. The prophet was therefore a spokesperson (Noth, p.184) of the oppressed and any complicity with the ruling elite led a prophet to be of questionable credentials. Such was the problem of 'prophet' Nathan, who is often referred to as a politician masquerading as a prophet. Many scholars find Nathan's association with David which resulted in David monopolizing the ruling dynasty of the Judah, and the unlikely Solomon acceding to power, nothing but politics in the gab of prophecy (Walsh \& Begg, 1990, pp.1623). A true Mosaic prophet like Samuel did not hesitate to replace Saul with David once he transgressed. Another important aspect in a prophet was that of delivering enduring prophecies. In other words the prophet's oracles were supposed to be fulfilled. It is important to note that, of all the qualities of a prophet, the test of moral character was the most enduring principle (Jeremiah 22-3).

The major type of prophecy in the Old Testament was that of forth-telling, meaning that the prophet made use of the prevailing situation to predict what tomorrow held in store for the people. The spirit of God helped him discern the situation properly. Scholars still find this prophetic voice in the collective voice of the Church today, especially with regard to the contemporary Church's concern for social justice. The Church is a kind of divine vigilante that focuses on the rights of the common man. Cognizant of this view, this paper seeks to discern the prophetic voice within the Anglican Communion of Central Africa during the whole period of the media feigned factionalism. How did the closeness of Kunonga to the President and his party impact on his priestly-prophetic office?

\section{iii) The Church of England: A Historical Background}

The Papacy assumed strict monogamy emanating from the Roman marriage as the only form of marriage acceptable. Marriage as a sacrament was indissoluble once consummated. It could only be declared null and void through the application of complicated forms of nullity administered solely by the church administration. King Henry VIII having failed to bear a son applied to divorce his wife, Catherine of Aragon, but the Vatican declared the marriage indissoluble (en.Wikipedia.org/wiki/). Failing to reconcile the traditional English spiritual obligation of a male heir with the papal demands, the king persuaded the Catholic Archbishop of Canterbury to sanction his divorce in exchange for favours. The temptation for power led the Archbishop to pull the Roman Catholic Province of England out of the fold, recognizing the king as the new supreme governor of the Church of England from 1531. The new dispensation seceded with the believers and the church property and it became legal that the denomination of the king was the denomination of the kingdom. Those who 
opposed the stance faced serious persecution. The wealth of the church accumulated over centuries passed into the hands of the Crown and the nobility, making it expedient for the priests to follow the crown in order to receive monetary incentives.

The colonial period saw the Church of England competing with other denominations for believers in the sprawling British Empire. In Southern Africa she established the Church of the Province of Central Africa (CPCA) which is now a synod of bishops from Botswana, Malawi and Zambia, and Zimbabwe (RelZim.org, 2011). The bishops in the various dioceses of the Province are elected, consecrated and evaluated in relation to the constitution and canons of the CPCA. The church properties of the dioceses are legally owned by the Province and no individual diocese can decide to secede or vary the decisions of the synod unilaterally.

This paper considers Nolbert Kunonga (the former Archbishop of the Diocese of Harare)'s spirited attempt to vary the decisions of the synod and secede from the Church of the Province of Central Africa (CPCA), and the charade of media barrage it attracted. The question is, 'Did Kunonga learn any lessons from the formation of the Church of England?'

\section{iv) The Zimbabwean Situation}

President Robert Mugabe is on record as saying that gay practice violates women rights. The morality of his stance is anchored in the biblical purpose for creating mates: "to be fruitful and multiply" (Genesis, $\left.1^{28}\right)$. Addressing a women empowerment conference in Harare he says: "Mothers were given a talent to bear children...When a man says he wants to get married to another man ... it would lead to extinction." (Bolonsky, 2012) Contradicting nature would make human beings worse than "pigs and dogs" deserving severe punishment by the law.

Kunonga's pastoral position made a neat dock with this presidential position; maintaining that the crisis was exacerbated by the consecration of gay Gene Robinson as bishop, then gay priests, followed by the blessing of same sex marriages. In addition, Kunonga disregarded the authority of the Archbishop of Canterbury who is appointed by the English monarch whose complicity in the imposition of sanctions on himself and senior ZANU PF officials he abhorred (Relzim.org. 2011).

Just after his election as Archbishop on December 22 2000, he openly sided with ZANU PF and started 'decolonizing' the Church; with his enthronement speech of May 052001 leaving white clergy and lay dumbfounded. "Church leaders rebuked Kunonga for preaching partisan politics from the pulpit" but he boasted of being "a proud and educated puppet" (RelZim.org., $2011 \mathrm{cf}$ Mutsaka, 2012) of ZANU PF and preferred to take the Diocese of Harare out of the CPCA. The CPCA then resolved to relieve him of his post in January 2008, prompting him to form the "indigenous" Anglican Church of the Province of Zimbabwe (ACPZ), as heir to the erstwhile properties and structures of the CPCA. By this he "broke his vow of obedience" (Hunter, 2011) to the constitution and canons of the CPCA, so he was ex-communicated and the retired Bishop Sebastian Bakare was consecrated in his place. In 2008 a high court ruling ordered Kunonga and his church to share the Anglican facilities with the CPCA, but instead Kunonga systematically persecuted the erudite clergy who in turn skipped his jurisdiction. What followed where running battles between the police and the CPCA followers resulting in a shooting incident in March 2009 which injured one CPCA lay person.

Canon Chad Gandiya succeeded Bakare in 2009, but in August 2011 the Chief Justice ruled that Kunonga was the rightful custodian of the Anglican properties in Zimbabwe. Kunonga went ahead and purged the churches, schools, hospitals and orphanages of all Gandiya sympathizers. Due to dwindling numbers, he leased churches to private schools and crèches, as converting churches into schools and universities had historical precedencies (RelZim.org., 2013).

When Rowan Williams the Archbishop of Canterbury visited Zimbabwe in October 2011, Kunonga presided over a protest march of $1000 \mathrm{ACPZ}$ faithful at the Anglican cathedral in Harare. He claimed that the 'spontaneous' protest objected to Williams' "crusade for gays," and when finally lost on the legal front on 19 November 2012, he refused to re-join the CPCA as an ordinary member (RelZim.org., 2013).

The paper intends to make in-roads into whether the portrayal of Kunonga by the media is made out of a prima face case. Some theories would see nothing but the contest for power between two competing factions and it is within the scope of this paper to determine the admissibility of this view.

\section{Public Opinion theory}

\section{Media Theories}

Public opinion is an aggregate of individual views, attitudes and beliefs about a particular topic expressed by a significant proportion of a community. According to Cutlip et al (1994, p. 24), the notion of public opinion holds that it is the aggregate of individual views on some issue. Cutlip (1994, p 26.) points out that this "individual" approach to defining public opinion however misses the point_"that it is public". He further posits that public opinion represents more than the collected views held by a particular group of individuals at one point in time but instead it reflects a "dynamic process in which ideas are expressed, adjusted and 
compromised en-route to collective determination of a course of action."

In political science, the central concept of most public opinion research remains the attitude. According to Gordon Allport (p.810) an attitude is a mental or neural state of readiness, organized through experience exerting a directive or dynamic influence upon the individuals' response to all objects and situations with which it is related." Theorists agree that attitudes are learned and involve consistent responses to objects and situations. Attitudes have three components:

- A cognitive element that links the object to information.

- An affective element that links the object to an evaluation or emotional reaction.

- A conative element that is an element that may link the object to actual behaviour.

A cognitive element of an attitude towards the Anglican Church management's conflict might be the perception that "Archbishop Kunonga is driven by a wealth accumulation agenda". This belief might not be an accurate reflection of the politics of church management, but it reflects what individuals aligned to the other faction believe to be true and is therefore a cognitive aspect of public opinion. An affective element would be the feeling behind the statement, "I'm angry that the Kunonga faction is tarnishing the image of the Church."

A conative element would be the behavioural intention, "I will write on my Facebook page lobbying for the removal of the Archbishop." Clyde Wilcox et al (p.72) argue that no consensus exists on just how attitudes relate to other concepts such as values, beliefs, opinions, habits and identifications, that is, aspects of personal identity.

The most frequently used attitude theory in political science has been cognitive dissonance theory which shall be applied to religion in covering events that unfolded in the Anglican Church. Leon Fistinger (1957, p.3) theorized that inconsistent attitudes or beliefs should cause some psychological discomfort and thus "motivate the person to try to reduce the dissonance and achieve consonance."

Steen Vallentin (2007) posits that public opinion refers to the mass mediated dimension of responsiveness: media exposure and opinion climates, public debates and representations of opinions that may be more or less insightful and qualified. Vallentine et al propound that public opinion as a concept embodies variety and thus provides a multi-faceted point of departure for reflections on the relationship between politics and society. Public opinion touches on all the main areas of politics and society, political environmental assessment, stakeholder management and issues management. The congregation's views becomes religious public opinion in the sense that Christians from the same denomination took sides with the leadership through comments in newspapers, posters, radio, television as well as through postings on Facebook, twitter, YouTube and other cyber platforms.

\section{Public Sphere concept}

Jurgen Habermas in his publication "The Structural Transformation of the Public Sphere" traces the development of the public sphere in the French salons and England's coffee houses respectively and he asserts that:

The coffee houses in their golden age between 1680 and 1730 and the salons in the period between regency and revolution were centres of criticism - literary at first, then also political in which emerged a certain party of the educated between aristocratic society and bourgeois intellectuals....There was scarcely a great writer in the eighteenth century who would not have first submitted his essential ideas for discussions in such discourses in lectures before the academic and especially in the salons (Habermas, 1962 / 1989, p.32).

In its original conceptualization, Habermas defined the Public sphere as,

...that realm of social life where the exchange of information and views on questions of common concern can take place so that public opinion can be formed." In the culture characterized by the public sphere ...there occurred a public space outside the control by the state where individuals exchanged views and knowledge (Habermas, 1962, p.56).

The public sphere concept has been adopted by various scholars and some have defined it as,

"a realm of our social life in which something approaching public opinion can be formed....Citizens behave as a public body when they confer in an unrestricted fashion-that is within the guarantee of freedom of assembly and association and the freedom to publish their opinions" (Pusey, 1978, p.89)

It has to be noted that in this study, the concept of the public sphere would be used to imply a platform where the researcher would engage Anglicans for the purpose of obtaining their views about the conflict of leadership that bedeviled the church. The feedback letters written to media houses would also constitute vital content as 
these are part of the public sphere. In that regard the letters written to newspaper by ordinary Anglicans would constitute a public sphere in this study.

\section{Agenda Setting Theory}

The agenda setting theory's origin can be traced back to the work of Lang and Lang (1959) though the key proponents are McCombs and Shaw (1972 and 1976). Agenda setting is the idea that the media can determine public thinking. The theory holds the view that the media can shape the thinking and behaviour of the public (Anglican congregation and fellow Zimbabwean readers).

Lang and Lang (1959) supporting the assertion states that "in a sense the newspaper is the prime mover in setting the territorial agenda. It has a great part in determining what most people will be talking about, what most people will think the facts are and what most people will regard as the way problems are to be dealt with (Lang and Lang, 1959, p.260)."

By omission, the audience is conditioned into some frame of mind. McQuail and Windhal (1993, p.40) point out that: "Audiences not only learn about public issues and other matters through the media, they also learn how much importance to attach to an issue or topic from the emphasis the mass media put upon it."

Lazarsfeld et al (1949 p.87) referred to it as the power to "structure issues". According to Rodgers and Dearing (1987, p26.) we need to distinguish clearly between three different agendas; "the priorities of the media; those of the public and those of policy."

The agenda setting theory builds on Lippman's (1922) notion of media impact by distinguishing between what we think about and what we think. The difference is that the former includes what we know about (cognition), whereas the later refers to our opinions and feelings (predispositions). Agenda setting suggests that mass media can have substantial and important impact on the cognitive level without affecting predisposition. Agenda setting results in a cumulative theory (related to cultivation). Cutlip (2004) posit that one can imagine the potential consequence of media agenda setting. First of all, media coverage can elevate the public standing of issues, people, organisations, institutions and so forth. Secondly, change in the amount of media attention can lead to changes in public priorities. Thirdly the more concerned people are about something the more they tend to learn about it, the stronger their opinions of it and the more they tend to take action on it. Fourth, media coverage can affect the agenda priorities of specific and important publics such as legislators, regulators and other policy makers. Mass communication can affect public opinion by raising the salience of issues and positions taken by people and groups in the news.

Cutlip (2004, p.82) concludes that "it is almost a logical truth that the media daily construct our perceptions of political reality". Walter Lippmann (1922) observed:

because each of us lives and works on a small part of the earth's surface, moves in a small circle, and of these acquaintances knows only a few intimately, we must each rely on stereotypes-ideas, theoriesthat make sense of the world beyond our direct experience. These stereotypes must reach us from external sources such as the media or else they must be projected outwards, either from the structure of our minds or from our personal experience, quite conceivably without justification. In short our ideas about the world have to come from somewhere and that somewhere in the modern world is usually the mass media (Lippmann, 1922, p.53).

In line with the agenda setting theory, the media in Zimbabwe took a leading role in informing and educating the populace on conflicts and legal suits that unfolded between the two feuding Anglican factions of the BakareGandiya led Church of the Province of Central Africa and the Kunonga founded Province of Zimbabwe. The study will thus strive to strike a balance between the messages communicated and the possible interpretations from the warring Anglican factions.

\section{Presentation and Representation of the Anglican Conflict in the Media}

The media in Zimbabwe presented the Anglican management conflict in a polarized manner. The polarization they reported followed the political polarization trends that are normally evident in the newspapers. The public media which normally supported President Mugabe and his party reported positively on Kunonga who publicly supported ZANU PF policies while the other two privately owned media reported positively on the Bakare-Gandiya led faction that sided with the Movement for Democratic Change. The public media on the one hand sided with Kunonga who shared a strong anti-homosexual sentiment with President Mugabe. Like true agenda setters, their views constituted public opinion as evidenced by letters written to the editors showing that the readers wrote to the newspapers that concurred with their views.

The media raised an array of issues from homosexuality, land reform and indigenization, church assets such as schools, hospitals and pre-schools that the management fought to control. There were also issues relating to partnerships within the church and with the political parties. Given the array of topics raised one wonders what really the bone of contention was and why other issues were brought up. The truth of the matter 
is that the real battle was for controlling the Anglican Church and all its assets and all the other matters raised were for supporting this cause. This would mean that the schismatic factor was political influence and priestly pre-eminence and the attempt to secede with believers and church properties brings back the memories of the sixteenth century when the Church of England was formed.

The Kunonga faction declared support and loyalty to ZANU PF and thus enjoyed externalities of associating with the party. The unprecedented support from Kunonga is highlighted in a message to parishioners during the annual Bernard Mizeki commemorations in Marondera on 16 June 2012. Edwin Mwase quotes him as saying: "The land reform and the indigenization programmes are not election gimmicks but matters of life, which seek to liberate the previously down-trodden Africans" (Mwase, 2012). He adds that Kunonga maintained that he would continue to support President Mugabe's black empowerment drive which is a "divine act of God" and that homosexuality was "ungodly."

The battle to control assets is highlighted by court challenges and counter challenges, evictions and counter evictions that ensued between the two feuding parties. Both the public and private media fairly covered court cases and followed with editorials taking sides and supporting a particular faction. For instance at the inception of the squabble, The Daily News led with a headline "From prime choice to rotten" (Mutsaka, 2012). The adjective rotten depicts the hatred and indeed the stance of the paper. It clearly highlighted that they did not support Kunonga's cause. Another headline in the Daily News of 25 November 2012 read "Kunonga, police in unholy alliance?" implying that emphasis was on Kunonga as a cunning and corrupt character who aspired to gain control of the church property by whatever means necessary (Chidza, 2012). The love for the Bakare faction by the private media is shown and lucidly headlined by the Zimbabwean which gives him prominence as an advisor. "Zimbabwe bishop warns about Mugabe's intentions" reads one headline where Bakare was expressing reservations about the sincerity of President Mugabe at the formation of the Inclusive Government (Grundy, 2008).

The private media depicts Kunonga as a wealth seeking clergyman who was after properties formerly belonging to the CPCA and the position on homosexuality was a non-event as the Supreme Court ruling centred on properties' ownership. In a letter given space in The Daily News, a reader Simbarashe asserts, "The judgment by the supreme court against Kunonga is befitting for a man who perniciously rejected God and sought earthly glories from men of flesh" (Simbarashe, 2012). This view was consistent with the conflict for assets thus the audience of the private media tallied with the agenda set by the medium of their choice.

Kunonga, the former Archbishop of the CPCA diocese of Harare, who moved out to form his own church (ACPZ) says he is the rightful inheritor of the Anglican property for which he had been made overseer by the CPCA. The CPCA says he is no longer a member of the CPCA and naturally has no right to those properties and the tag of war goes on with no side relenting until the very last article where Kunonga gives in to the Supreme Court order to relinquish the properties to the CPCA represented by Bishop Chad Gandiya. The Zimpapers report that most churches were rented out to schools, crèches and colleges with students learning around the altars. Kunonga's daughter had the crèche at the heart of the Anglican diocesan centre of authority, the Anglican cathedral. In one story the Harare police spokesperson reports that one Rev. Naboth Manzongo of the APCA had sustained a deep head cut from the Kunonga assailants and the culprits were known but no arrests had yet been made (Nemukuyu \& Taadira, 2012). In the process of implementing the Supreme court order the deputy sheriff was manhandled and his assistant only managed to operate with a beefed up police complement. Other denominations leaders while urging reconciliation urged the Kunonga faction to be law abiding Christians; realizing that as they had moved out of the CPCA they should naturally accept the consequences.

The public opinion expressed by the people highlighted divisions and polarization. The contributors openly took sides with their particular leader. The articles against homosexuality were given generous space in opinions (Masosote, 2012; Manheru, 2012) in the public media which show consistency with Kunonga antihomosexuality stance. These two articles dogmatize the question of same sex marriage from the religious, psychological, sociological and existential imperatives. The first article notes that homosexuality "is freedom gone too far." The second one is a satirical comment about the origins of the Anglican Church from "marital divorce" and therefore the current schism based on the marriage type (homosexuality or heterosexuality) is no stranger to Anglicanism; the faith of "the king's zip and throne." The author maintains that each type of marriage has proponents among the two factions and the factions have found partnerships in different political parties. The current problem has been exacerbated by one religious minister wanting to date another minister and the succession to the throne in the original schism has been succeeded by the succession to the mace (meaning that King Henry VIII's heirless to the throne is equivalent to the CPCA's heirless mace). The author is particularly intrigued by the fact that in their final success the CPCA supporters celebrated in churches with open palms which for him is a sign of affiliation to a political party, the MDC, a perennial adversary of ZANU PF whose sign he notes as the clenched fist. He praises President Mugabe, then a godless Marxist, for his doctrine of reconciliation towards his vanquished erstwhile adversaries at independence in 1980. The final analysis is in favour of the official Kunonga position that he should not be demonised for the new schism in a 
church whose faith is based on mundane things, with no theological foundation to its original formation.

After the final court decision that decided in favour of the CPCA the few articles that attempted an analysis tended to group Kunonga with ZANU PF. The Herald Leader Comment of 21 November 2012 for the first time noted that Kunonga may have been in error. It says, "And a similar split was probably seen among Dr Kunonga's supporters. His efforts to politicize the dispute certainly cost him the support of many who initially followed him and caused many others to think seriously about what he was saying as matters grew bitterer." In spite of this observation the paper called for reconciliation, in its leader comment entitled "Anglicans' legal victory must unite the church." The comment notes that the ruling was a confirmation of what was obviously expected. The said ruling was not about leadership of the congregation but superintendence over properties. It notes that the followers of Kunonga have never been in the majority though some genuinely believed him. It wishes him success as the Methodists did when they broke off from the Anglican Church if he wishes to remain outside the Church of England.

In a letter entitled "homosexuality should be criminalized" (Mash, 2012) the author Cde. Mash says that the MDC secretary general Mr. Tendai Biti and the MDC spokesman Mr. Douglas Mwonzora are in error in emphasizing only prohibition of homosexual marriage and not homosexual practices. The letter emphasizes that the country cannot afford to go the Swedish and French ways and therefore the homosexual practices must be criminalized in the national constitution. No article with a different perspective was given space.

\section{Conclusion}

The study proved that the media was driven by the profit motive and the interests of their owners. This is evidenced by the fact that they went along with the political stances or editorial policies of their newspapers. The public media which support ZANU PF openly took sides with Kunonga while the private media did the opposite. The media maximized on the political and religious polarization existent in the country to further their own market interests. The media from both ends did not strike a balance in their stories and there is no evidence of objectivity; thus it can be said that in covering the Anglican squabble the media was not neutral. The headline "Kunonga threatens to shoot journos" in the News Day of November 292012 shows the animosity and bad blood that existed between the bishop and practitioners from the private media (Chidavaenzi \& Nleya, 2012). The agenda set by the media as well as the letters they gave coverage lucidly attest to the fact that the media was not neutral in Anglican saga as is expected of them. The leadership of the church as evidenced by the outcomes of the court challenges as reported by the press was more concerned with controlling assets and less worried about the congregation they "shepherded" thus they were erring from their religious obligations to worldly concerns.

In the final analysis the succession to the mace was seen as schismatic as the CPCA fought to dethrone Kunonga who held on to the mace with a conglomerate of reasons unacceptable to his erstwhile masters. The private media saw a repetition of the NathanZadok-Bathsheba-Beniah usurping faction in Kunonga and his close associates and blew the whistle for him to be removed. In the scheme of the private media Kunonga had clearly digressed from the traditional scheme of gaining and relinquishing authority and should not be allowed to follow the primrose path of his predecessors; the chief priest Zadok and the 1532 bishop of Canterbury, who caused schisms with serious consequences. Because of the court's intervention the finally schism was smooth and less consequential. The public media acknowledges Kunonga as allocating divine acts to the president, which is true of the chief priest Zadok in the case of David and the archbishop of Canterbury's acknowledgement of King Henry VIII's divine authority in the governance of the Church of England. The private media on the other hand sees Kunonga as heretical in divinizing presidential acts; and possibly failing to distinguish between the divine office of the king and the secular president.

The media is visibly split on the allocation of prophetic authority, with the public media saying it lies with the moralizing Kunonga and the private media saying it lies with the traditional Bakare-Gandiya faction. In the end the public media breaks the taboo and reprimands Kunonga for politicizing the Anglican Management Conflict and confusing his former faithful followers. By politicizing the conflict both sides agree that Kunonga erred and by implication credits the Bakare-Gandiya faction with the enduring prophetic oracles. Both sides accept the court ruling as legitimate and as long expected, albeit with different registers, seemingly leaving the candidates of the private media in the prophetic council of God. 


\section{References}

[1]. Anderson, B. W. (1975). The Living World of the Old Testament. New Jersey: Prentice-Hall Inc.

[2]. Cutlip M (1994): Effective Public Relations, Prentice hall Inc, New Jersey

[3]. Ewbank R. A. B. (1994). Prophets of the Old Testament. Harare: College Press.

[4]. Habermas J (1989). The Structural Transformation of the Public Sphere. Cambridge, MA:MIT Press.

[5]. Lang, G. and Lang, K. (1983) The battle for Public Opinion. New York: Columbia University Press.

[6]. Lazarsfeld et. al (1949) Communication Research 1948-9. New York: Harper and Row

[7]. Lippmann, W. (1922) Public Opinion. New York: Harcourt Brace.

[8]. McCombs and Shaw (1972 \& 1976) The Agenda-setting function of the Press, Public Opinion Quarterly.

[9]. McQuail and Windahl (1993) Communication models for the study of Mass Communication, Second Edition. London: Longman.

[10]. Noth, M., "History and the word of God in the Old Testament," pp.179-193 cited in Anderson, B. W. (1975). The Living World of the Old Testament. New Jersey: Prentice-Hall Inc.

[11]. Rodgers and Dearing (1987). Agenda setting research: Where has it been? Where is it going? Newbury Park, CA: Sage

[12]. Valentine (2007). Private Management and Public Opinion-Corporate Social Responsiveness Revisited. London: Sage Publications.

[13]. Walsh T. T.\& Begg C. T. (1990). The Jerome Biblical Commentary

[14]. Wilcox C. and Norrander B (2002): The Diverse Paths to Understanding Public Opinion, Washington: CP Press.

[15]. The Holy Bible (RSV)

[16]. News Papers

[17]. Chidavaenzi, P. \& Nleya, F. (2012, November 29). Kunonga threatens to shoot journos. News Day, p.1.

[18]. Chidza, R. (2012, November 25). Kunonga, police in unholy alliance? Daily News, p.7.

[19]. Comment. (2012, November 21). Anglicans' legal victory must unite the church. The Herald, p.5.

[20]. Grundy, T. (2008, July 31-August 6). Zimbabwe bishop warns about Mugabe's intention. The Zimbabwean, p. 9.

[21]. Manheru, N. (2012, December 1). Anglican Church - When secular sin sours the holy soul. The Herald, pp. 4,7 .

[22]. Mash, Cde. (2012, November 04-10). Homosexuality must be criminalised. The Sunday Mail, p. 7.

[23]. Masosote, T. (2012, January 15-21). Gay rights: Freedom gone too far. The Sunday Mail, p.9

[24]. Mutsaka, F. (2012, November 25). From Prime Choice to Rotten. Daily News, p.5.

[25]. Mwase, A. (2012, June 17-23). Indigenisation an act of God - Kunonga. Sunday Mail, p.

[26]. Nemukuyu, D. \& Taadira, E. (2012, December 1). The Herald, pp.1,3.

[27]. Simbarashe (2012, November 27). Kunonga got himself into trouble. Daily News, p. 9.

[28]. Internet Sources

[29]. A.Bolonski. (2012, May 24). Robert Mugabe claims gays violate women's rights. Retrieved from www.towleroad.com. (2013, March 1).

[30]. A.Hunter. (2011). Letter from Dean. Retrieved from www.scifac.ru.ca.zw/cathedral/spire/novll/dean/htp (2013, March 1)

[31]. History of the Church of England from Wikipedia, the free encyclopedia. Retrieved from en.wikipedia.org/wiki/History of the Church of England. (2013, March 1).

[32]. RelZim.org/resources/religious-leaders-zimbabwe/nolbert kunonga. (2013, March 1). 